Abstracta Iranica Abstracta Iranica

Revue bibliographique pour le domaine irano-aryen

Volume 22 | 2001

Comptes rendus des publications de 1999

\title{
«Material Aspects of Achaemenid Polychrome Decoration and Jewellery », IA, 33, (1998), pp. 155-171, Mélanges en l'honneur de David Stronach.
}

\section{Astrid Nunn}

\section{(2) OpenEdition}

1 Journals

\section{Édition électronique}

URL : http://journals.openedition.org/abstractairanica/36365

DOI : 10.4000/abstractairanica.36365

ISSN : 1961-960X

Éditeur :

CNRS (UMR 7528 Mondes iraniens et indiens), Éditions de l'IFRI

\section{Édition imprimée}

Date de publication : 15 mai 2001

ISSN : 0240-8910

Référence électronique

Astrid Nunn, " « Material Aspects of Achaemenid Polychrome Decoration and Jewellery », IA, 33,

(1998), pp. 155-171, Mélanges en I'honneur de David Stronach. », Abstracta Iranica [En ligne], Volume 22 |

2001, document 155, mis en ligne le 15 février 2010, consulté le 10 octobre 2020. URL : http:// journals.openedition.org/abstractairanica/36365; DOI : https://doi.org/10.4000/abstractairanica. 36365

Ce document a été généré automatiquement le 10 octobre 2020.

Tous droits réservés 


\title{
« Material Aspects of Achaemenid Polychrome Decoration and
}

\section{Jewellery ", IA, 33, (1998), pp. 155-171, Mélanges en l'honneur de David Stronach.}

\author{
Astrid Nunn
}

L'A. s'intéresse à la technique du cloisonné. Cette technique se retrouve sous forme émaillée dans les rares bijoux achéménides qui ont survécu et... dans l'art achéménide des briques vernissées. En effet la spécialité achéménide par rapport à ses antécédents babyloniens est de cerner le dessin d'un gros trait noir et de se rapprocher ainsi de l'apparence du cloisonné. Un passage du texte de fondation de Suse écrit par Darius I. indique que ses joailliers étaient mèdes et égyptiens et que les artisans chargés d'orner les murs étaient également mèdes et égyptiens. De quelle technique ornementale s'agitil ? D'autre part certains bas-reliefs (à Persépolis dans le Tripylon ou à Pasargades) étaient réellement pourvus d'applications en pierre ou métaux précieux. S'agit-il de ce travail dans le texte? et exécuté par des artisans mèdes et égyptiens? L'A. essaie de reconstruire l'origine (lointainement égyptienne) et l'évolution du cloisonné dans la bijouterie achéménide, tout en insistant sur l'interaction des artisans de toutes origines et tout particulièrement sur le rôle des artisans déportés d'Égypte en Perse par Darius et d'autres Grands Rois. 
INDEX

Thèmes : 3.2.2. Pré-Achéménides et Achéménides

\section{AUTEURS}

ASTRID NUNN

Université de Munich (Allemagne) 